\title{
Application of Customer Relationship Marketing Towards Customer Loyalty Through Trust in Bank
}

\author{
Angga Ade Permana, Muhammad Firdaus, Muhaimin Dimyati \\ Master of Management Study Program, Mandala Jember College of Economics \\ Email: anggaadepermana23@gmail.com
}

\section{A R T ICLE INFO}

Date of entry:

10 July 2020

Revision Date:

25 August 2020

Date Received:

18 September 2020

\begin{abstract}
A B S T R A C T
Customer relationship marketing as a strategy to build good relationships with customers in the long run by combining the ability to respond directly and to serve customers with high interaction. The purpose of this study is whether customer relationship marketing influences customer loyalty through trust, directly or indirectly. The sampling technique that researchers took was Nonprobability sampling and using purposive sampling. The type of research method used in this research is path analysis, t-test, determination $\mathrm{R}^{2}$. The path analysis results show that the variable component of customer relationship marketing which includes commitment and conflict handling has a significant direct relationship to trust and loyalty while communication does not have a negative influence or a negative effect on customer trust or loyalty.
\end{abstract}

Keywords: Customer Relationship Marketing, Trust, Loyalty

Cite this as: Permana, A. A., Firdaus, M., Dimyati, M. (2020). Application of Customer Relationship Marketing Towards Customer Loyalty Through Trust in Bank. Wiga : Jurnal Penelitian Ilmu Ekonomi, 10(2), 179-190. https://doi.org/10.30741/wiga.v10i2.622

\section{INTRODUCTION}

The economic development in the world is currently very fast, especially in the field of banking. Banking as one of the financial industries registered with the Financial Services Authority experienced significant progress in Indonesia, resulting in intense competition nationally and even globally. In addition to rivals among conventional banks, there are also Islamic banks, BPRs, and other financial institutions. Banking companies began to be encouraged to further strengthen their strategic base by prioritizing customer satisfaction and loyalty. Companies that want to excel must have a strategy in winning competition, including strategies in attracting customers, retaining customers, and managing customers. How customers can be loyal and increase the level of trust in the company.

Companies are required to be able to understand customers more closely so that there is a beneficial relationship between the two parties. (Kotler \& Keller, 2009) states that companies that want to increase their sales profits must spend a lot of time and resources finding new customers. In order to acquire new customers, they grow their marketing through advertisements and place 
them in media that will reach new markets. In 2017, Banyuwangi Branch Bank of East Java has managed to raise funds in the form of savings in the amount of Rp.15,583,200 billion which grew by Rp1,398,687 billion or $9.86 \%$ from 2016. The biggest contribution in increasing savings funds in 2017 which reached $75.96 \%$ was Simpeda Savings. While other savings products are Cycle Savings with a contribution of $13.08 \%$, TabunganKu contributed $9.54 \%$, Savings Hajj Banyuwangi Branch Bank of East Java with a contribution of 1.20\%, and Student Savings $0.22 \%$. The Laku Pandai Deposits contributed very little because it was only launched in November 2016. Savings growth in 2017 was also followed by an increase in the number of savings customers recorded as many as 5,383,502 customers, and in 2016 as many as 4,969,813 customers.

In creating customer loyalty, banks must create customer satisfaction. One of the strategies carried out by banks in increasing customer loyalty is by implementing customer relationship marketing. (Ndubisi, 2003) argues that the company must make changes and investments that are useful in building relationships with loyal customers, or at least how customers become loyal. One of the strategies carried out by banks in improving the quality of service to consumers is by implementing customer relationship marketing, through a commitment to service, communication with customers, and handling customer complaints as a focus in building good relationships with customers (Ndubisi, 2007). Flexible communication and the best commitment in serving customers, as well as the ability to handle complaints become important roles in building and increasing customer confidence (Bowo Nursatyo Heri, 2003)

With communication, commitment, and being able to conflict handling, it makes customers loyal to banks. One of them is by improving the quality of service. According to (Kasmir, 2013) Good service is a person's ability to provide services that can make customer satisfaction according to customer desires. The main objective of Relationship Marketing is to maximize customer equity, the total value of the customer's survival in the company (Kotler \& Keller, 2009).

(Morgan \& Hunt, 1994) commitment is basically a long-standing desire in customers to maintain a valuable relationship or a relationship that provides benefits (valued relationship), that customers will have a strong or high commitment if the relationship is considered important. (Morgan \& Hunt, 1994) explain that commitment is a promise, pledge or seller's determination to establish an ongoing relationship with the buyer.

Communication according to (Kotler \& Keller, 2009) is a process used by consumers and marketing organizations to share information in order to achieve mutual understanding. The important thing to note, if the reception of the information is good, will spread widely to the target audience, especially in introducing new products. Information obtained by consumers will usually relate to decisions taken (Semuel, 2012). (Nelson \& Chan, 2005) give results a good relationship between conflict handling and customer loyalty, indirectly through trust and relationship quality. The ability of product or service providers to handle conflicts properly will also directly affect customer loyalty.

Conflict handling according to (Dwyer et al., 1987) is conflict handling as the ability to avoid heavier conflicts, resolve real conflicts before they cause new problems, and discuss solutions openly related to problems when problems arise so that no major conflicts arise. (Morgan \& Hunt, 1994) explains that trust has a meaning that is a key variable in maintaining a long-lasting relationship, including as in a brand. According to (Maharani, 2010) trusted is one party's belief in the truth and integrity of the other party in the actual relationship and convincing that the other party's actions can influence the other. Thus, if trust has been applied, there will be no conflict.

Loyalty is a commitment that is firmly held by consumers to buy or return to buy a product or service that is needed at a later date even though the influence of marketing conditions has the potential to cause customers to switch. (Oliver, 2010). Creating strong and close customer relationships is the dream of all marketers and this is often the key to long-term marketing success (Kotler \& Keller, 2009). 
Relationship marketing is a marketing strategy undertaken by companies to maintain and improve customer satisfaction through customer values. Customer relationship marketing is one of the strategies used by companies by utilizing internal resources (such as technology, employees, and processes) to create a competitive advantage and improve company performance. Companies that manage consumer information well are believed to have a competitive advantage in the long term (Mohammed \& Bin Rashid, 2012); (Mushtaq Ahmad Darzi, 2016). The strategy adopted to achieve this is by creating stable and good relationships with consumers. In a good relationship, the company will get customer loyalty (Mohammed \& Bin Rashid, 2012).

This CRM must be done as one of the latest innovations to keep customers in the midst of increasingly fierce competition. By using CRM, the company has ensured that the company is run with the system and used properly by its employees. As well as to ensure customer satisfaction, it is important to receive personal feedback. So, the company knows what is the problem why customers are loyal to the bank. Based on the introduction and theory obtained, the hypothesis in this study are: H1: Allegedly commitment to influence on trust in the Banyuwangi Branch Bank of East Java, H2: Allegedly communication to influence on trust in the Banyuwangi Branch Bank of East Java, H3: Allegedly conflict handling to influence on trust in the Banyuwangi Branch Bank of East Java, H4: Allegedly commitment to influence on loyalty to the Banyuwangi Branch Bank of East Java, H5: Allegedly communication to influence on loyalty in Banyuwangi Branch Bank of East Java, H6: Allegedly confllict handling to influence on loyalty to the Banyuwangi Branch Bank of East Java, H7: Allegedly trust to influences on customer loyalty in the Banyuwangi Branch Bank of East Java, H8: Allegedly trust to mediate between commitment, communication, and conflict handling on customer loyalty at Banyuwangi Branch Bank of East Java.

\section{METHOD}

Population is the entire research subject or the total number of a sample, both quantitative and qualitative, of the characteristics that have certain characters that will be used as the basis for sampling. (Usman \& Akbar, 2009). To determine the sample, the population taken is all customers of Banyuwangi Branch Bank of East Java who are directly involved in the transaction. This research uses a quantitative approach to determine the effect of the independent variables to dependent variable. The sample in this study were customers who met the requirements with a purposive sampling method. Researchers used purposive sampling with the provisions that they had been customers for at least 5 years, the customers examined in the Banyuwangi Branch Bank of East Java savings products were Savings savings products, consisting of Simpeda, East Java Bank Hajj Savings, Savings, Cycles, Student Savings. Determination of the number of samples in this study in order to be good according to (Hair et al., 1995) is depending on all indicators of all variables multiplied by 5 to 10 . The number of samples in this study were: Sample = number of indicators x $5=25 \times 5=125$ respondents.

Based on the theory from (Hair et al., 1995), the sample in this study is a minimum of 125 respondents. So, for the sample taken 125 respondent samples at Banyuwangi Branch Bank of East Java customers. Researchers used purposive sampling provided that they had been customers for at least 5 years, the customers examined in the Banyuwangi Branch Bank of East Java savings product were Savings savings products, consisting of Simpeda, East Java Bank Hajj Savings, Savings, Cycles, Student Savings.

Data analysis techniques in this study will be done by using path analysis models with IBM SPSS 21Previously, the application of the instrument in this study would be tested for research using a questionnaire that had to be tested for validity and reliability before going directly to the company. Validity test can be seen from the significance value by comparing the value of $r$ arithmetic with $r$ table for degree of freedom $(\mathrm{df})=\mathrm{n}-2$ in this case $\mathrm{n}$ is the number of samples. Meanwhile, to find out the score of each question item is valid or not (Ghozali, 2013), the statistical criteria are set as 
follows; 1. If $r>r$ table and is positive, then the variable is valid, 2. If $r<r$ table and is negative, then the variable is invalid (Ghozali, 2013) Measurement of reliability can be done in two ways, namely, if the value of alpha $>0.7$ means that reliability is sufficient (sufficient reliability) while if alpha > 0.80 suggests all reliable items and all tests consistently internally because they have reliable reliability. strong. Or, some interpret it as follows: 1) If alpha $>0.90$, the reliability is perfect. 2) If alpha is between $0.70-0.90$ then high reliability, 3) If alpha is between $0.50-0.70$ then moderate reliability, 4) If alpha $<0.50$ then reliability is low.

According to (Ghozali, 2013) the influence of mediation variable can be detected directly by looking at the following model; $\mathrm{Y}=\mathrm{a} 1+\mathrm{cX}$ (Release 1), $\mathrm{m}=\mathrm{a} 2+\mathrm{cXI}$ (Release 2), $\mathrm{Y}=\mathrm{a} 3+\mathrm{c}^{\prime} \mathrm{X}$ $+\mathrm{bM}$ (Release 3 ). The variable $\mathrm{M}$ is called mediator or intervening if press 1 ( $\mathrm{X}$ ) significantly influences $\mathrm{Y}$ (or $\mathrm{c} \neq 0$ ), press $2(\mathrm{X})$ significantly influences $\mathrm{M}$ (or $\mathrm{a} \neq 0$ ), press 3 ( $\mathrm{X}$ ) significantly influences $\mathrm{Y}$ by controlling $\mathrm{M}($ or $\mathrm{b} \neq 0)$.

According to (Ghozali, 2013), states that: "Path analysis is a technique for analyzing the causal relationship that occurs in multiple regression if the independent variable affects the dependent variable not only directly but also indirectly". Path analysis itself does not determine a cause-effect relationship and also cannot be used as a substitute for researchers to see the causality relationship between variables.

Basically, the path coefficient is a standardized regression coefficient ( standardized regression weights ) or compares the coefficient of indirect effects (indirect effects ) with the coefficients of direct effects ( direct effects). The regression equation based on (Ghozali, 2013) can be formulated into: Sub-structure 1 (the influence of the Independent variables on the dependent variable). $Z=$ px1z X1 + px2z X2 + px3z X3 + el Equation ......... (1). Sub-structure 2 (influence between independent variables on the dependent variable through interveing variables)

$\mathrm{Y}=\mathrm{px} 1 \mathrm{y}+\mathrm{px} 3 \mathrm{y}+\mathrm{pzy}+\mathrm{e} 2$ Equation

Trimming theory is a model used to improve a structural model of path analysis by removing itself from the exogenous variable model whose path coefficient is not significant. According to (Ghozali, 2013) model which is not significant after eliminating the path is no longer included in the calculation, then the calculation is carried out again by formulating a new structural equation (without including the variable whose path is not significant). a) Calculating direct effect (direct effect or DE) : 1. The influence of Customer Relationship Marketing variables on trust. Dezx $=\mathrm{X}$ $\rightarrow Z$, 2. The influence of Customer Relationship Marketing variables on customer loyalty. Deyx = $X \rightarrow Y$, 3. The influence of the variable of trust on consumer loyalty. Deyz $=Z \rightarrow Y$. b) Count indirect effects (indirect effects or IE). The influence of Customer Relationship Marketing variables on customer loyalty through trust. IeyzX $=X \rightarrow Z \rightarrow Y$.

\section{RESULTS AND DISCUSSION}

Description of Respondent Characteristics. Questionnaires were given as many as 150 sheets and those that were declared eligible to be processed were 125 questionnaires.

Table 1. Age of Respondents

\begin{tabular}{ccccc}
\hline \multirow{2}{*}{ Age } & \multicolumn{3}{c}{ Male } & \multicolumn{2}{c}{ Female } \\
\cline { 2 - 5 } & Total & $\mathbf{\% \%}$ & total & Percentage \% \\
\hline $21-30$ & 18 & $35.3 \%$ & 36 & $48.6 \%$ \\
$31-40$ & 33 & $64.7 \%$ & 38 & $51.4 \%$ \\
Total & 51 & $100 \%$ & 74 & $100 \%$ \\
\hline
\end{tabular}

Source: Data processed (2019) 
The statement of the questionnaire submitted was the most age with the number of 74 respondents in the female sex. With an age range of 31-40 respondents as many as 38 years and while 36 respondents range in age from 21-30 years. And the remaining 51 respondents in the male sex. With an age range of 31-40 respondents as many as 33 years and while 18 respondents range in age from 21-30 years.

Table 2. Gender

\begin{tabular}{|c|c|c|}
\hline Gender & Number of Respondents & Percentage $\%$ \\
\hline Male & 51 & $40.8 \%$ \\
\hline Female & 74 & $59.2 \%$ \\
\hline Total & 125 & $100 \%$ \\
\hline
\end{tabular}

Source: Data processed (2019)

The number is 51 respondents with male gender and 74 of them are female. From these results, the average respondent who saved and utilized the facilities provided by the Banyuwangi Branch Bank of East Java was female.

Table 3. Types of Savings

\begin{tabular}{lcc}
\hline \multicolumn{1}{c}{ Savings Type } & $\begin{array}{c}\text { Number of } \\
\text { Customers }\end{array}$ & Percentage \% \\
\hline Simpeda & 42 & $33.6 \%$ \\
East Java Bank Hajj Savings & 14 & $11.2 \%$ \\
My savings & 31 & $24.8 \%$ \\
Cycle & 30 & $24 \%$ \\
Student Deposits & 8 & $6.4 \%$ \\
Total & 125 & $100 \%$ \\
\hline
\end{tabular}

Source: Data processed (2019)

Based Table 3 above, it can be seen that for the kind of savings that answered questions on a questionnaire submitted is with the numbers 42 respondents majority of respondents have savings deposits on the type Simpeda. 31 respondents have savings in my savings type. 30 respondents have savings in the type of cycle. As many as 14 respondents have savings deposits in the types of hajj bank savings accounts. Eighty respondents have savings in the type of student savings. From these results, the majority of respondents who saved at the Banyuwangi Branch Bank of East Java were simpeda types.

Table 4. Types of Work

\begin{tabular}{lcc}
\hline \multicolumn{1}{c}{ Type of work } & Total & Percentage \% \\
\hline Government employees & 43 & $34.4 \%$ \\
Private employees & 32 & $25.6 \%$ \\
Volunteer & 24 & $19.2 \%$ \\
entrepreneur & 26 & $20.8 \%$ \\
Total & 125 & $100 \%$ \\
\hline
\end{tabular}

Source: Data processed (2019)

The customers who answered the questions on the questionnaire for the type of work submitted were the majority who were civil servants with a number of 43 respondents. Then 32 respondents worked as private employees. 26 respondents work as entrepreneurs. And as many as 24 respondents work as sukwan. From these results, the majority of respondents who save at the Banyuwangi Branch Bank of East Java are working as civil servants. 
Table 5. Customer Salary

\begin{tabular}{lcc}
\hline \multicolumn{1}{c}{ Salary } & total & Percentage \% \\
\hline <Rp. 1,500,000 / month & 30 & $24 \%$ \\
Rp. 1,500,000 / month to Rp. 3,000,000 / month & 56 & $44.8 \%$ \\
Rp. 3,000,000 / month to Rp. 5,000,000 / month & 23 & $18.4 \%$ \\
> IDR 5,000,000 / month & 16 & $12.8 \%$ \\
Total & 125 & $100 \%$ \\
\hline
\end{tabular}

Source: Data processed (2019)

Based on table 5 above. It can be seen that the customers who answered the questions on the questionnaire respondents' salary submitted were the majority earning $\mathrm{Rp} 1,500,000$ / month to $\mathrm{Rp}$ $3,000,000$ with a number of 56 respondents. Then 30 respondents earning <Rp 1,500,000. As many as 23 respondents earned between Rp. 3,000,000 / month to Rp. 5,000,000. And 16

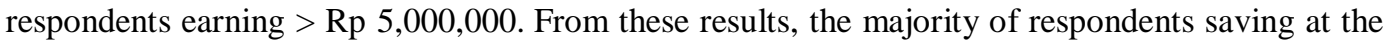
Banyuwangi Branch Bank of East Java are earning an average of $\mathrm{Rp} 1,500,000$ / month to $\mathrm{Rp}$ $3,000,000$.

Path coefficient value shows the overall effect of variable $X_{1}, X_{2}$, and $X_{3}$ to variable $Z$. path analysis results are presented in table 6 below ;

Table 6. Model 1. Path Analysis Test Results Coefficients $^{\text {a }}$

\begin{tabular}{|c|c|c|c|c|c|c|}
\hline & \multirow[t]{2}{*}{ Model } & \multicolumn{2}{|c|}{$\begin{array}{c}\text { Unstandardized } \\
\text { Coefficients }\end{array}$} & \multirow{2}{*}{$\begin{array}{c}\begin{array}{c}\text { Standardized } \\
\text { Coefficients }\end{array} \\
\text { Beta } \\
\end{array}$} & \multirow[t]{2}{*}{$\mathrm{t}$} & \multirow[t]{2}{*}{ Sig } \\
\hline & & $\mathrm{B}$ & Std. Error & & & \\
\hline \multirow{4}{*}{1} & (Constant) & 1,025 &, 326 & & 3,143 &, 002 \\
\hline & Commitment &, 252 &, 097 &, 257 & 2,610 &, 010 \\
\hline & Communication &,- 079 & 080 &,- 078 & -982 &, 328 \\
\hline & Conflict handling &, 523 &, 116 &, 469 & 4,493 &, 000 \\
\hline
\end{tabular}

a. Dependent Variable: Trust

Source; Data processed (2019)

Referring to the Regression output Model 1 in the " coefficient " table, it can be seen that the significance value of the three variables is different, namely the commitment variable $\left(\mathrm{X}_{1}\right)$ which is 0.010 and the conflict handling variable $\left(\mathrm{X}_{3}\right)$ equal to 0.00 , while the communication variable $\left(\mathrm{X}_{2}\right)$ is 0.328 . Wherefrom the results it means that if the regression results one significance value < (smaller) than 0.05 then it has a significant effect, as well as if the significance value > (greater) than 0.05 then, has no effect. From these results provide a conclusion that the variable commitment $\left(\mathrm{X}_{1}\right)$ and conflict handling $\left(\mathrm{X}_{3}\right)$ significantly influence trust $(\mathrm{Z})$. While communication $\left(\mathrm{X}_{2}\right)$ has no effect on trust $(\mathrm{Z})$.

Table 7. Determination Test Model Summary Model

\begin{tabular}{ccccc} 
Model & R & R Square & Adjusted R Square & Std. Error of the Estimate \\
\hline 1 & $0,643^{\text {a }}$ & 0,413 & 0,399 & 0,5381 \\
\hline
\end{tabular}

a. Predictors: (Constant), Conflict Handling, Communication, Commitment

Source; Data processed (2019)

The value $R_{\text {square }}$ in the "Model Summary" table is 0.413 . This shows that the influence of the three variables commitment $\left(\mathrm{X}_{1}\right)$, communication $\left(\mathrm{X}_{2}\right)$ and conflict handling $\left(\mathrm{X}_{3}\right)$ trust $(\mathrm{Z})$ is 0.413 or $41.3 \%$, while the remaining $58.7 \%$ is contributed by other variables not included in the research, 
meanwhile, for the value of e1 can be found with the formula $\mathrm{e} 1=\sqrt{(1-0,413)}=$ 0.7662.Therefore obtained the path diagram of structure model 1 as follows;

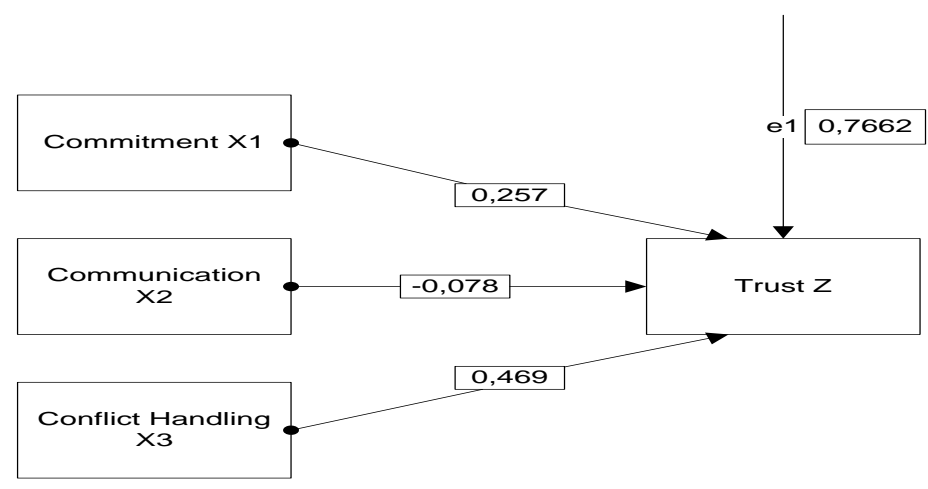

Figure 1. Structure Results 1

Source; Data processed (2019)

Based on Figure 1. a structural equation pathway model is obtained as follows: $\mathrm{Z}=0,257 \mathrm{X}_{1^{-}}$$0,078 \mathrm{X}_{2}+0,469 \mathrm{X}_{3}+\mathrm{e} \ldots$. (equation 1$)$

Path coefficient value shows the overall effect of variable $\mathrm{X}_{1}, \mathrm{X}_{2}$, and $\mathrm{X}_{3}$ to variable $\mathrm{Z}$, the overall effect of variable $X_{1}, X_{2}, X_{3}$ and $Z$ to variable $Y$, and the influence of the variable $Z$ to variable $Y$. The path analysis results are presented in Table 8 below;

Table 8. Path Analysis Test Results Model 2

$$
\text { Coefficients }^{\text {a }}
$$

\begin{tabular}{llccccc}
\hline \multicolumn{1}{c}{ Model } & \multicolumn{2}{c}{$\begin{array}{c}\text { Unstandardized } \\
\text { Coefficients }\end{array}$} & $\begin{array}{c}\text { Standardized } \\
\text { Coefficients } \\
\text { Beta }\end{array}$ & t & Sig. \\
& B & Std. Error & & & \\
\hline \multirow{2}{*}{1 Constant) } & 0,635 & 0,264 & & 2,405 & 0,018 \\
& Commitment & 0,273 & 0,077 & 0,292 & 3,523 & 0,001 \\
& Communication & $-0,075$ & 0,063 & $-0,078$ & $-1,196$ & 0,234 \\
& Conflict Handling & 0,268 & 0,098 & 0,252 & 2,732 & 0,001 \\
& Customer Trust & 0,370 & 0,071 & 0,390 & 5,231 & 0,000 \\
\hline
\end{tabular}

a. Dependent Variable: Loyalty

Source; Data processed (2019)

Referring to the Regression output Model 2 in the " coefficient " table, it can be seen that the significance value of the three variables is the commitment variable $\left(\mathrm{X}_{1}\right)$ which is 0.001 the conflict handling variable $\left(\mathrm{X}_{3}\right)$ is 0.001 and the trust variable $(\mathrm{Z})$ is 0,000 while the communication variable $\left(\mathrm{X}_{2}\right)$ is 0.234 . Where from the results it means that if the regression results of two significance values <(smaller) than 0.05 then the significant effect, as well as if the significance value $>$ (greater) than 0.05 then, no effect. From these results it can be concluded that the variables of commitment $\left(\mathrm{X}_{1}\right)$, conflict handling $\left(\mathrm{X}_{3}\right)$, and trust $(\mathrm{Z})$ have a significant effect on customer loyalty ( $\mathrm{Y}$ ). While communication $\left(\mathrm{X}_{1}\right)$ has no effect on customer loyalty ( $\mathrm{Y}$ ).

Table 9. Determination Test Model 2

\section{Summary Model}

\begin{tabular}{ccccc} 
Model & R & R Square & Adjusted R Square & $\begin{array}{c}\text { Std. Error of the } \\
\text { Estimate }\end{array}$ \\
\hline 1 & 0,781 & 0,610 & 0,597 & 0,4192 \\
\hline
\end{tabular}

a. Predictors: (Constant), Trust, Communication, Commitment, conflict Handling 
Source; Data processed (2019)

The value $\mathrm{R}_{\text {square }}$ in the " Model Summary " table is 0.610 . This shows that the influence of the four variables commitment $\left(\mathrm{X}_{1}\right)$, communication $\left(\mathrm{X}_{2}\right)$, conflict handling $\left(\mathrm{X}_{3}\right)$ and trust $(\mathrm{Z})$ on customer loyalty is 0.610 or $61 \%$ while the remaining $39 \%$ is contributed by other variables not included Meanwhile, for the value of e 2 can be found with the formula $\mathrm{e} 2=\sqrt{(1-0,610)}=$ 0.6245.Therefore obtained the path diagram of structure 1 model as follows;

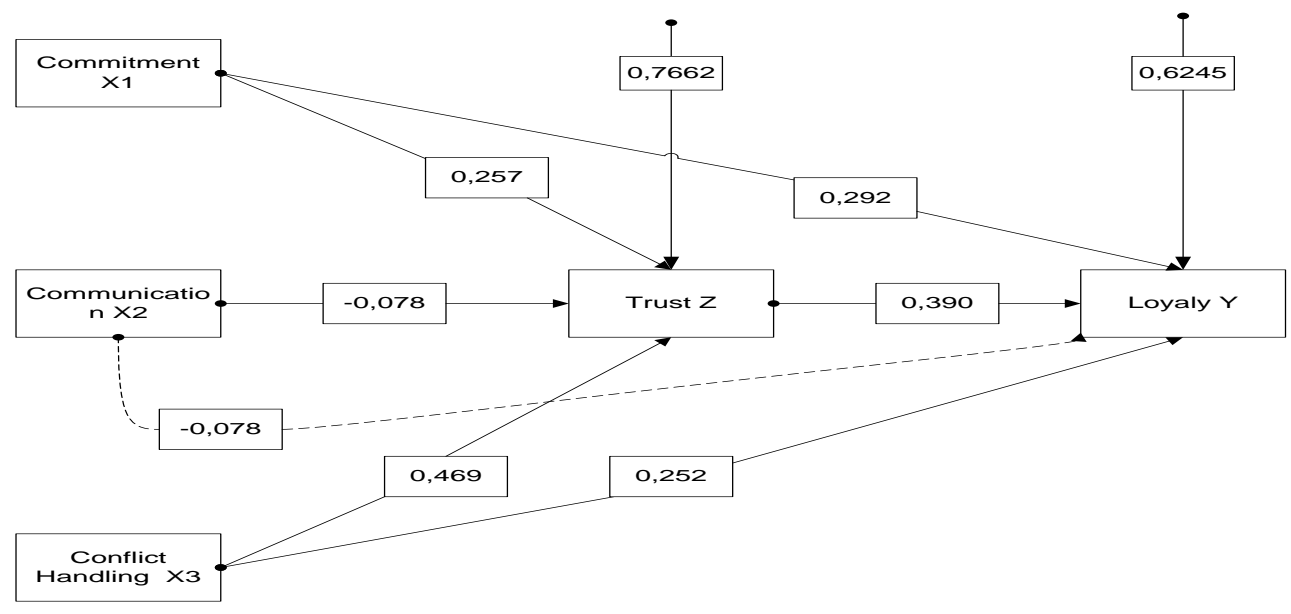

Figure 2. Structure Results 2

Source; Data processed (2019)

Based on Table 9 , the structural equation pathway model is obtained as follows ; $\mathrm{Z}=0,257 \mathrm{X}_{1}$ $0,078 X_{2}+0,469 X_{3}+$ e $\ldots . .$. ( equation 1$), Y=0,257 X_{1}-0,078 X_{2}+0,469 X_{3}+0,039 Z+E$ ..... ( equation 2)

Based on the results of the table 10 All the paths significantly unless variabel communication $\left(\mathrm{X}_{2}\right)$ has a value of significance is more than $0,05(\mathrm{p}>0.05)$ or is a track that is not significant, then the communication variables $\left(\mathrm{X}_{2}\right)$ should be deleted . Proof of models new to the tally after the conducted test track back without having to include the variable $\left(\mathrm{X}_{2}\right)$ is as follows :

Table 10. Trimming Theory Results

\begin{tabular}{|c|c|c|c|c|c|c|}
\hline \multicolumn{3}{|c|}{$\begin{array}{c}\text { Standarized } \\
\text { Pathway }\end{array}$} & Beta & Sig & $\alpha$ & Information \\
\hline $\mathrm{X} 1$ & $\rightarrow$ & $\mathrm{Z}$ & .231 & 0,000 & 0.05 & Significant \\
\hline $\mathrm{X} 3$ & $\rightarrow$ & $\mathrm{Z}$ & .453 & 0.002 & 0.05 & Significant \\
\hline $\mathrm{X} 1$ & $\rightarrow$ & Y & .312 & 0.004 & 0.05 & Significant \\
\hline $\mathrm{X} 3$ & $\rightarrow$ & $\mathrm{Y}$ & .352 & 0,000 & 0.05 & Significant \\
\hline $\mathrm{Z}$ & $\rightarrow$ & Y & .218 & 0.002 & 0.05 & Significant \\
\hline
\end{tabular}

Source: Data processed (2019)

Based on table 10 To analyze the first path can be explained that between Commitment $\left(\mathrm{X}_{1}\right)$ with trust $(Z)$ has a significant effect. This can be seen by the results of a significant value that is 0,000 less than $\alpha=0.05$. The second path between conflict handling $\left(\mathrm{X}_{3}\right)$ with trust $(\mathrm{Z})$ has a significant effect that is equal to 0.002 smaller than $\alpha=0.05$. The third line between commitment $\left(\mathrm{X}_{4}\right)$ and loyalty (Y) have a significant effect in the amount of 0,004 is smaller than $\alpha=0.05$. The fourth path between conflict handling $\left(\mathrm{X}_{3}\right)$ with loyalty $(\mathrm{Y})$ has a significant effect of 0,000 which is smaller than $\alpha=0.05$. The fifth path between Trust (Z) and Loyalty (Y) has a significant effect that 
is equal to 0.002. Having carried out the elimination of the variable Communications $\left(\mathrm{X}_{2}\right)$ are not significant, obtained equation structural $Y$ are new, namely: $Z=0,231 X_{1}+0,453 X_{3}+e$ ...... (Equation 3$), \mathrm{Y}=0,312 \mathrm{X}_{1}+0,352 \mathrm{X}_{3}+0.218 \mathrm{Z}+\mathrm{e} \ldots \ldots$ (Equation 4$)$

Based on the results of the path analysis and then explained in the trimming theory that the variables are not significant, the variables are eliminated. From these results, the determination test can be seen as follows;

Table 11. The coefficient of determination $\left(\mathbf{R}^{2}\right)$

\begin{tabular}{ccccc}
\hline Model & R & R Square & Adjusted R Square & $\begin{array}{c}\text { Std. Error of the } \\
\text { Estimate }\end{array}$ \\
\hline 1 & $0,883^{\mathrm{a}}$ & 0,841 & 0,611 & 0,4241 \\
\hline
\end{tabular}

a. Predictors: (Constant), Trust, Commitment, Conflict Handling

Source: Data processed (2019)

The value $\mathrm{R}_{\text {square }}$ in the " Model Summary " table is 0.841 . This shows that the influence of the four variables commitment $\left(\mathrm{X}_{1}\right)$, conflict handling $\left(\mathrm{X}_{3}\right)$ and trust $(\mathrm{Z})$ on customer loyalty is 0.841 or $84.1 \%$ while the remaining $15.9 \%$ is contributed by other variables not included in research.

Detecting the Effects of Mediation, a. Direct influence : The commitment variable $\left(\mathrm{X}_{1}\right)$ influences trust $(\mathrm{Z})$ is 0,231 , The conflict handling variable $\left(\mathrm{X}_{3}\right)$ gives an influence on trust $(\mathrm{Z})$ is equal to 0,453 , The commitment variable $\left(\mathrm{X}_{1}\right)$ gives effect to loyalty $(\mathrm{Y})$ of 0,312 , The conflict handling variable (X3) has an effect on loyalty (Y) of 0,352 , The belief variable (Z) influences loyalty (Y) of 0,218. b. Indirect influence : Analysis of the effect of commitment $\left(\mathrm{X}_{1}\right)$ through trust $(\mathrm{Z})$ on loyalty $(\mathrm{Y})$.

Given the direct effect given commitment $\left(\mathrm{X}_{1}\right)$ of 0.231 on trust $(\mathrm{Z})$. While the indirect effect of commitment $\left(\mathrm{X}_{1}\right)$ through trust $(\mathrm{Z})$ on customer loyalty $(\mathrm{Y})$ is the multiplication of commitment beta value $\left(\mathrm{X}_{1}\right)$ on trust $(\mathrm{Z})$ with commitment beta value $\left(\mathrm{X}_{1}\right)$ on loyalty $(\mathrm{Y})$, namely; $0.231 \times 0.312=0.072$. Thus, the influence of trust $(Z)$ which becomes an intervening variable or mediates between commitment $\left(\mathrm{X}_{1}\right)$ to customer loyalty $(\mathrm{Y})$ of 0.072 .

It is known that the direct effect is given conflict handling $\left(\mathrm{X}_{3}\right)$ of 0.453 on trust $(\mathrm{Z})$. While the indirect effect of conflict handling $\left(\mathrm{X}_{3}\right)$ through trust $(\mathrm{Z})$ on customer loyalty $(\mathrm{Y})$ is the multiplication between the beta value of conflict handling $\left(\mathrm{X}_{3}\right)$ on trust $(\mathrm{Z})$ and conflict handling $\left(\mathrm{X}_{3}\right)$ beta value on loyalty $(\mathrm{Y})$, namely; $0.453 \times 0.352=0.159$. Then, the influence of trust $(\mathrm{Z})$ which becomes an intervening variable or mediates between conflict handling $\left(\mathrm{X}_{3}\right)$ and customer loyalty $(\mathrm{Y})$ is 0.159 .

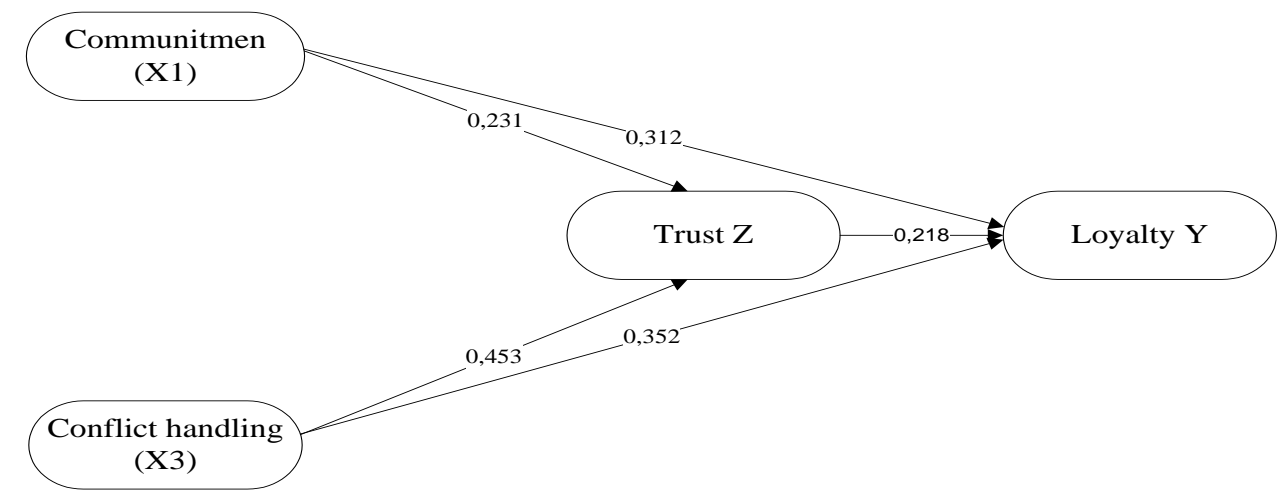

Figure 3. Trimming Theory Model

Source; Data processed (2019) 


\section{CONCLUSION}

This study examines the effect of local government characteristics and BPK audit reports on provincial governments' performance in Indonesia with the conclusions: Size of the region, level of regional wealth, population, and BPK audit opinion does not significantly influence the performance of provincial government in Indonesia. Meanwhile, BPK's audit findings have a significant negative effect on provincial, local governments' performance in Indonesia. This conclusion has implications for provincial, local governments in Indonesia that: 1) The BPK audit findings on local government performance have a significant negative effect. This means that the greater the value of BPK's audit findings, the lower the local governments' performance. The regional government should pay attention to the prevailing laws and regulations in managing regional finances to minimize audits that indicate State losses by the BPK. With a low finding value, local governments' performance will increase, which will have an impact on improving the welfare of the community. 2) As measured by total assets and the level of regional wealth as measured by the original regional income, the size of the region has no significant effect on the performance of local governments. The total assets and revenue of this region affect but not significant. It is better if the local government, which is oriented towards the community's welfare, should be able to manage assets and local revenue properly.

\section{REFERENCE}

Agung, R. I. G. (2011). Audit Kinerja Pada Sektor Publik. Jakarta: Salemba Empat

Andriani, Y. Analisis Pengaruh Kompetensi Politik, Tingkat Pendidikan dan Jumlah Penduduk Terhadap Tingkat Pengungkapan Informasi Non Keuangan dalam Website Pemerintah Daerah Kabupaten dan Kota di Sumatera. Artikel Ilmiah. Universitas Negeri Padang

Anton. (2010). Menuju Teori Stewardship Manajemen. Majalah ilmiah Informatika Vol.1 No.2 Mei 2010

Ara, S. C. (2016). Pengaruh Karakteristik Pemda dan Temuan Audit BPK Terhadap Kinerja Pemda Kabupaten di Pulau Sumba. JAFFA Vo. 04 No.1 April 2016 Hal. 1-17

Azis, A. (2016). Pengaruh Karakteristik Pemerintah Daerah Terhadap Kinerja Keuangan Pemerintah Daerah (Studi Pada Pemerintah Daerah Kabupaten/ Kota di Jawa Timur). EKSIS Vol XI No.1, 2016: 87- 101

BPK RI. (2017). Ikhtisar Hasil Pemeriksaan Semester I Tahun 2017. Jakarta: BPK RI

Budianto, W. (2012). Pengaruh Opini, Temuan Audit dan Gender terhadap Kinerja Penyelenggaraan Pemerintah Daerah Kabupaten/ Kota di Indonesia Tahun 2008- 2010

Darise, N. (2007). Pengelolaan Keuangan Daerah. Jakarta: PT Indeks

Ghaniyyu dan Amir. (2015). Pengaruh Karakteristik Pemerintah Terhadap Tingkat Pengungkapan Laporan Keuanagan Pemerintah Daerah Di Indonesia. Accounting Analysis Journal 4 (2). Universitas Negeri Semarang

Gudono. (2012). Teori Organisasi Edisi 2. Yogyakarta: BPFE

Hudayati, A. (2002). Perkembangan Penelitian Akuntansi Keperilakuan: Berbagai Theori dan Pendekatan Yang Melandasi. FE Universitas Islam Indonesia, JAAI Volume 6 No.2, Desember 2002: 81-96

Juweny, S. (2016). Pengaruh Karakteristik Pemerintah Daerah dan Temuan Audit BPK Terhadap Kinerja Pemerintah Daerah Provinsi di Indonesia. Tesis. Universitas Lampung

Kementerian Keuangan. Kajian Kependudukan. (2015). Jakarta: Direktorat Jenderal Anggaran Kementerian Keuangan

Keputusan Menteri Dalam Negeri Nomor 100 - 53 Tahun 2018 Tentang Penetapan Peringkat dan Status Kinerja Penyelenggaraan Pemerintahan Daerah Secara Nasional

Keputusan Badan Pemeriksa Keuangan Republik Indonesia Nomor 14/K/I-XIII.2/9/2017 Tentang Perubahan Keempat Atas Keputusan Badan Pemeriksa Keuangan Nomor 3/K/IXIII.2/7/2014 Tentang Organisasi Dan Tata Kerja Pelaksana Badan Pemeriksa Keuangan. 
Kusumawardani, M. (2012). Pengaruh Size, Kemakmuran, Ukuran Legislatif, Leverage Terhadap Kinerja Keuangan Pemerintah Daerah di Indonesia. Accounting Analysis Journal 1 (1) (2012): 28-33

Mahsun, M. (2013). Pengukuran Kinerja Sektor Publik Edisi Pertama. Yogyakarta: BPFE

Mangkunegara, I. (2015). The Effect Of Financial Characteristic And Audit Findings On The Public Welfare In The North Sumatera Province. Journal BPK RI December 215: 141155

Mardiasmo. (2009). Akuntansi Sektor Publik. Yogyakarta: CV Andi Offset

Marfiana, N. \& Kurniasih, L. (2013). Pengaruh Karakteristik Pemerintah Daerah dan Hasil Pemeriksaan Auit BPK Terhadap Kinerja Keuangan Pemerintah Daerah Kabupaten/Kota. Fakultas Ekonomi Universitas Sebelas Maret Surakarta

Martono, N. (2011). Metode Penelitian Kuantitatif: Analisis Isi dan Analisis Data Sekunder. Jakarta: RajaGrafindo Persada

Masdiantini, P. R. dan Erawati. N. M. A. (2016). Pengaruh Ukuran Pemerintah Daerah, Kemakmuran, Intergovermental Revenue, Temuan Dan Opini Audit BPK Pada Kinerja Keuangan. E-Journal Akuntansi Universitas Udayana.14.2 Februari (2016).1150-1182

Maskhuri. (2017). Pengaruh Kompensasi dan Kepuasan Kerja Terhadap Komitmen Organisasi. Skripsi. Universitas Muhmammadiyah Jakarta.

Meilina, Z. D. dkk. (2016). Pengaruh Karakteristik Pemerintah Daerah dan Hasil Pemeriksaan BPK Terhadap Kinerja Pemerintah Daerah (Studi pada Kota/Kabupaten di Provinsi Jawa Barat Tahun 2010-2014). E-Proceeding of Management: Vol3. No.3.Universitas Telkom

Mustikarini, W. A, Fitriasari, D. (2012). Pengaruh Karakteristik Pemerintah Daerah dan Temuan Audit BPK terhadap Kinerja Pemerintah Daerah Kabupaten/Kota di Indonesia Tahun Anggaran 2007. Jawa Barat: Universitas Indonesia

Nanda, V. (2017). Pengaruh Karakteristik Pemerintah Daerah Dan Temuan Audit BPK Terhadap Kinerja Pemerintah Daerah Kabupaten/Kota (Studi Kasus di Kabupaten/Kota seSumatera Tahun Anggaran 2013-2014). Skripsi. Univeritas Lampung

Noviyanti, N. A. dan Kiswanto. (2016). Pengaruh Karakteristik Pemerintah Daerah, Temuan Audit BPK Terhadap Kinerja Keuangan Pemerintah Daerah. Accouting Analysis Journal 5 (1) (2016): $1-10$

Nugroho, R. A. (2014). Pengaruh Karakteristik Pemerintah Daerah dan Temuan Audit BPK Terhadap Kinerja Pemerintah Daerah. Skripsi. Universitas Diponegoro

Nurtari, Almanita, Fadilla, S. dan Nucholisah, K. (2016). Pengaruh Karakteristik dan Komplektisitas Pemerintah Daerah terhadap Pengungkapan Laporan Keuangan. Prosiding Akuntansi ISSN: 2460-6561 Volume 2, No.1 Tahun 2016: 263-270

Peraturan Badan Pemeriksa Keuangan Republik Indonesia Nomor 3 Tahun 2011 Tentang Pengelolaan Informasi Publik pada Badan Pemeriksa Keuangan.

Peraturan Badan Pemeriksa Keuangan Republik Indonesia Nomor 1 Tahun 2017 Tentang Standar Pemeriksaan Keuangan Negara.

Peraturan Menteri Dalam Negeri Nomor 73 Tahun 2009 Tentang Tata Cara Pelaksanaan Evaluasi Kinerja Penyelenggaraan Pemerintahan Daerah.

Peraturan Pemerintah Republik Indonesia Nomor 6 Tahun 2008 Tentang Pedoman Evaluasi Penyelenggaraan Pemerintahan Daerah.

Peraturan Pemerintah Republik Inonesia Nomor 3 Tahun 2007 Tentang Laporan Penyelenggaraan Pemerintahan Daerah Kepada Pemerintah, Laporan Keterangan Pertangungjawaban Kepala Daerah Kepada Dewan Perwakilan Rakyat Daerah, Dan Informasi Laporan Penyelenggaraan Pemerintahan Daerah Kepada Masyarakat.

Prasetyaningsih, E. (2014). Pengaruh Karakteristik Keuangan Daerahdan Temuan Audit Terhadap Kinerja Pemerintah Daerah Se-Indonesia. Tesis. Universitas Sebelas Maret

Priyatno, D. (2012). Belajar Cepat Olah Data Statistik dengan SPSS. Yogyakarta: CV Andi Offset

Purnama, Anggun. 2015. Pengaruh Karakteristik Pemerintah Daerah Dan Hasil Pemeriksaan Keuangan BPK Terhadap Kinerja Keuangan Pemerintah Daerah. Skripsi. STIE Indonesia.

Jones, R. G. (2001). Organizational Theory Text and Cases Third Edition. America: Prentice Hall 
Rasyid, E. R. (2015). Accounting-in-action: Teori Kontingensi dan Relativitas Budaya Sistem Akuntansi Manajemen.Yogyakarta: Pustaka Sempu

Sekaran, U. (2006). Research Methods for Business, Metodologi Penelitian untuk Bisnis, Edisi 4, Buku 2. Jakarta: Salemba Empat.

Sudarmadji, A. M. dan Sularto, L. (2007). Pengaruh Ukuran Perusahaan, Profitabilitas, Leverage, dan Tipe Kepemilikan Perusahaan terhadap Luas Voluntary Disclosure Laporan Keuangan Tahunan. Proceeding Psychology, Economy, Art, Architect and Civil. Gunadarma University

Sudarsana, H. S. dan Rahardjo, S. N. (2013). Pengaruh Karakteristik Pemerintah Daerah dan Temuan Audit BPK Terhadap Kinerja Pemerintah Daerah (Studi Pada Pemerintah Kabupaten/ Kota di Indonesia). Diponegoro Journal Of Accounting Vo.2, Nomo 4, Tahun 2013: 1-13

Suhardjanto, D. dan Yulianingtyas, R. R. (2011). Pengaruh Karakteristik Pemda terhadap Kepatuhan Pengungkapan Wajib dalam Laporan Keuangan Pemda (Studi Empiris pada Kabupaten/Kota di Indonesia). Jurnal Akuntansi \& Auditing, Volume 8/No.1/November 2011: 1-194.

Sujarweni, V. W. (2014). SPSS Untuk Penelitian. Yogyakarta: Pustaka Baru Press

Susiyah, H. Y., Afifudin dan Mawardi, M. C. (2016). Pengaruh Karakteristik Pemda Terhadap Tingkat Pengungkapan Laporan Keuangan di Website Pemda. Universitas Islam Malang

Syafitri, F. (2012). Analisis Pengaruh Karakteristik Pemerintah Daerah Terhadap Tingkat Pengungkapan Laporan Keuangan. Skripsi. Fakultas Ekonomi Universitas Indonesia

Undang- Undang Republik Indonesia No.14 Tahun 2008 Tentang Keterbukaan Informasi Publik

Undang-Undang Republik Indonesia Nomor 15 Tahun 2004 Tentang Pemeriksaan Pengelolaan dan Tanggung Jawab Keuangan Negara.

Undang-Undang Republik Indonesia Nomor 15 Tahun 2006 tentang Badan Pemeriksa Keuangan.

Undang-Undang Republik Indonesia Nomor 2 Tahun 2015 tentang Penetapan Peraturan Pemerintah Penggati Undang-Undang Nomor 2 Tahun 2014 Tentang Perubahan Atas Undang-Undang Nomor 23 Tahun 2014 Tentang Pemerintahan Daerah Menjadi UndangUndang.

Undang-Undang Republik Indonesia Nomor 23 Tahun 2014 tentang Pemerintahan Daerah.

Undang-Undang Republik Indonesia Pasal 26 Tentang Warga Negara dan Penduduk

Wibowo. (2016). Manajemen Kinerja Edisi Kelima. Jakarta: Rajawali Pers

Wijaya, T. (2013). Metodologi Penelitian Ekonomi dan Bisnis Teori dan Praktik. Yogyakarta: Graha Ilmu

. Mengenal Lebih Dekat BPK. Jakarta: Biro Humas BPK RI

(2016). Research Methods for Business: Metodologi Penelitian untuk Bisnis. Buku 1 Edisi 4. Jakarta: Salemba Empat. 